\title{
PENERAPAN METODE DRILL UNTUK MENINGKATKAN HASIL BELAJAR MATEMATIKA EKONOMI MAHASISWA PENDIDIKAN EKONOMI UNIVERSITAS PAMULANG
}

\author{
SYAFAATUL HIDAYATI ${ }^{1}$, SAIFUL ANWAR ${ }^{2}$ \\ ${ }^{1}$ Dosen Program Studi Pendidikan Ekonomi Universitas Pamulang \\ ${ }^{2}$ Dosen Program Studi Pendidikan Ekonomi Universitas Pamulang \\ *) email: $\underline{\text { dosen00861@unpam.ac.id }}{ }^{1}, \underline{\text { dosen00902@ unpam.ac.id }}{ }^{2}$
}

\begin{abstract}
ABSTRAK
Tujuan penelitian ini adalah untuk mengetahui penerapan Metode Drill dan untuk mengetahui apakah penerapan Metode Drill dapat meningkatkan hasil belajar matematika ekonomi mahasiswa pendidikan ekonomi di Universitas Pamulang. Dalam penelitian ini, data yang dikumpulkan bersifat deskriptif yaitu mengenai uraian-uraian pembelajaran mahasiswa. Penelitian ini menggunakan pendekatan kualitatif dengan jenis Penelitian Tindakan Kelas (PTK). Penelitian dilakukan dalam konteks kelas yang bertujuan untuk memperbaiki praktek pembelajaran di kelas, sehingga dapat meningkatkan hasil belajar mahasiswa. Temuan penelitian menunjukkan bahwa ada beberapa tahapan yang dilaksanakan dalam kegiatan pembelajaran dengan penerapan metode Drill, antara lain: (1) penyajian materi; (2) latihan terkontrol; (3) latihan mandiri; dan (4) tes. Disamping itu hasil belajar dalam bentuk tes disetiap akhir siklus I dan II mengalami peningkatan. Adapun peningkatan hasil belajar dari siklus I ke siklus II sebesar 22,73\%.
\end{abstract}

\section{Kata Kunci: Metode Drill, Hasil Belajar, Mahasiswa}

\section{PENDAHULUAN}

Menurut Lie (2008:54) seorang guru professional harus mempunyai pengetahuan dan persediaan strategi, metode-metode pembelajaran. Seorang Guru yang ingin maju dan berkembang perlu mempunyai persediaan strategi, tehnik, dan metode pembelajaran yang pasti akan selalu bermanfaat dan melaksanakan kegiatan belajar mengajar sehari-hari.

Sementara itu menurut James dalam Suherman (2001:16) matematika merupakan konsep ilmu tentang logika 
mengenai bentuk, susunan, besaran, dan konsep-konsep yang berhubungan satu dengan yang lainnya dengan jumlah yang banyak, yang terbagi ke dalam tiga bidang yaitu: aljabar, analisis, dan geometri.

Apapun pendekatan yang digunakan dalam proses pembelajaran, harus menempatkan siswa sebagai pusat perhatian utama supaya suasana belajar menjadi tidak menegangkan dan mahasiswa termotivasi untuk belajar, sehingga nantinya dapat meningkatkan hasil belajarnya. Demikian halnya dalam belajar Matematika Ekonomi, tentu memerlukan keterampilan dari seorang Dosen supaya anak didik mudah memahami materi yang diberikan. Apabila Dosen kurang menguasai strategi mengajar, maka mahasiswa akan sulit menerima materi pelajaran dengan sempurna. Oleh karena itu seorang Dosen dituntut untuk mengadakan inovasi dan berkreasi dalam melaksanakan pembelajaran, sehingga siswa lebih termotivasi dan hasil belajar yang dicapai siswa nantinya dapat memuaskan.

Capaian pembelajaran yang seharusnya dicapai mata kuliah Matematika Ekonomi yaitu: mahasiswa mampu memahami dan terampil dalam mengaplikasikan ilmu matematika dalam menyelesaikan masalah-masalah ekonomi melalui pembelajaran berbasis masalah. Dalam hal ini dituntut penggunaan metode pembelajaran yang tepat supaya kegiatan belajar mengajar menyenangkan. Sehingga nantinya tidak ada siswa yang mengeluhkan bahwa Matematika Ekonomi adalah mata kuliah yang sulit.

Melalui wawacara dan observasi tidak terstruktur terhadap pembelajaran di pendidikan ekonomi, masih terdapat beberapa dosen yang masih kurang mengaktifkan siswa dalam proses pembelajarannya. Mahasiswa masih kurang memahami dan kurang terlatih dalam latihan soal yang diberikan khususnya mata kuliah yang berupa hitungan. Salah satu penyebabnya dosen yang bersangkutan masih kurang bervariasi dalam penggunaan metode pembelajaran di kelas.

Apabila permasalahan diatas dibiarkan, mahasiswa kurang terlatih dan akan mempengaruhi kemampuannya dalam hitungan, serta secara langsung akan berdampak pula pada hasil belajar mereka. Padahal mengingat mahasiswa pendidikan 
ekonomi adalah calon guru dan nantinya akan melaksanakan kegiatan PPL tentu dibutuhkan penguasaan materi sebagai bekal nanti di lapangan saat praktik. Untuk itu diperlukan solusi yang tepat untuk mengatasi hal tersebut. Terdapat banyak metode yang dapat diterapkan Dosen pada saat proses belajar mengajar, salah satunya adalah metode drill.

Metode drill merupakan satu bentuk metode latihan, atau metode training dimana metode ini merupakan suatu cara mengajar yang baik untuk menanamkan kebiasaankebiasaan tertentu. Disamping itu juga sebagai sarana untuk memperoleh suatu ketangkasan, ketepatan, kesempatan dan keterampilan" (syaiful sagala, 2009:21).

Berdasarkan latar belakang diatas, maka peneliti ingin melaksanakan penelitian tindakan kelas (PTK) dengan judul Penerapan Metode Drill untuk Meningkatkan Hasil Belajar Matematika Ekonomi Mahasiswa Pendidikan Ekonomi Universitas Pamulang.

\section{Rumusan Masalah}

1. Bagaimana penerapan Metode Drill pada mata kuliah Matematika
Ekonomi Mahasiswa Pendidikan Ekonomi di Universitas Pamulang?

2. Apakah penerapan Metode Drill dapat meningkatkan hasil belajar matematika ekonomi mahasiswa pendidikan ekonomi di Universitas Pamulang?

\section{PENDEKATAN DAN JENIS}

\section{PENELITIAN}

Penelitian ini menggunakan pendekatan kualitatif dengan jenis Penelitian Tindakan Kelas (PTK). Penelitian ini menggunakan penelitian tindakan kelas, karena berdasarkan hasil observasi dan wawancara tidak terstruktur yang dilakukan dengan mahasiswa pendidikan ekonomi didapat informasi bahwa pemahaman mereka terhadap materi hitungan kurang, sehingga berdampak pada hasil belajarnya. Dengan demikian, maka perlu kiranya dicari solusi yang tepat untuk mengatasi hal tersebut. Dalam penelitian ini, peneliti melakukan eksperimen yang secara langsung dari awal sampai akhir proses penelitian. Dalam melakukan eksperimen ini, peneliti secara khusus mengamati secara terus menerus dan dilihat kekurangannya untuk kemudian diadakan pengubahan kontrol sampai 
pada upaya maksimal dalam bentuk tindakan yang tepat.

\section{Kehadiran Peneliti}

Peneliti dalam penelitian ini berperan sebagai instrumen kunci, karena sesuai dengan jenis penelitiannya, yaitu penelitian tindakan kelas. Dalam hal ini, kehadiran ataupun keterlibatan peneliti sangat mutlak dilakukan. Sebelum penelitian dilakukan, maka peneliti terlebih dahulu bertemu dengan mahasiswa dan menjelaskan tentang pembelajaran kooperatif kepada mereka sebelum penelitian ini dilaksanakan.

\section{Lokasi Penelitian}

Penelitian ini dilaksanakan pada mahasiswa Pendidikan Ekonomi Universitas Pamulang. Dimana lokasi penelitian dilakukan di FKIP Program Studi Pendidikan Ekonomi Universitas Pamulang. Alamat Jl. Raya Puspiptek, Buaran, Pamulang, Kota Tangerang Selatan, Banten 15310.

\section{Keterbatasan Penelitian}

1. Penelitian ini hanya mendeskripsikan penerapan metode drill untuk meningkatkan hasil belajar mahasiswa pendidikan ekonomi di Universitas Pamulang.
2. Penelitian ini hanya dilaksanakan pada mata kuliah Matematika Ekonomi tahun pelajaran ganjil 2018/2019.

3. Materi pelajaran yang digunakan dalam penelitian ini adalah fungsi linier pada pajak dan subsidi.

4. Hasil belajar diukur melalui tes hasil belajar pada akhir pertemuan.

\section{Prosedur Pengumpulan}

\section{Data}

Dalam penelitian ini, yang mengumpulkan data penelitian adalah peneliti sendiri melalui tes dan catatan lapangan. Pada penelitian ini, instrumen yang digunakan adalah sebagai berikut.

1) Soal Tes

Tes dalam penelitian ini meliputi soal uraian pada siklus 1 dan siklus II dianalisis untuk mengetahui ketuntasan belajar mahasiswa matakuliah matematika ekonomi.

2) Catatan Lapangan

Catatan lapangan memuat deskripsi tentang aktivitas-aktivitas mahasiswa dan dosen selama pembelajaran berlangsung. Catatan lapangan dibuat pada tiap-tiap pertemuan. 


\section{Analisis Data}

Analisis data dilakukan dengan cara mengumpulkan data-data yang diperoleh selama penelitian, kemudian data tersebut ditelaah dan diolah melalui kategori data. Dalam penelitian ini, data dianalisis secara deskriptif kualitatif. Analisis data ada tiga tahap yaitu: reduksi data, penyajian data, penarikan kesimpulan dan verifikasi.

\section{Evaluasi}

Kegiatan evaluasi terutama mengacu kepada keefektifan tindakan dan kesesuaian dampak tindakan dengan apa yang diharapkan peneliti. Sebagai upaya untuk menjamin keabsahan data dalam penelitian ini, maka dilakukan: 1) perpanjangan keikusertaan; 2) ketentuan pengamatan dan 3) triangulasi.

\section{Refleksi}

Refleksi ini dilakukan setiap akhir siklus I dan siklus II. Hal ini dilakukan untuk mengetahui sejauh mana keberhasilan dari tindakan yang dilakukan. Apabila tindakan dinilai belum seefektif yang diharapkan dan dampak yang ditimbulkan belum memenuhi harapan, peneliti mencoba mencari jawaban mengapa hal tersebut terjadi.

\section{PROSEDUR PENELITIAN}

Penelitian ini dilakukan dalam dua siklus. Pelaksanaan penelitian ini mengikuti tahap-tahap penelitian tindakan kelas yang terdiri dari observasi awal, siklus satu dan siklus dua. Adapun dalam setiap siklus penelitian terdiri dari empat tahap, yaitu merencanakan tindakan (planning), melakukan tindakan (action), mengamati tindakan (observation), dan melakukan refleksi (reflection). Pelaksanaan siklus kedua sama dengan siklus pertama.

\section{PAPARAN DATA}

\section{Kegiatan Pra Penelitian}

Pada tahap ini peneliti melakukan observasi dan wawancara tidak terstrutur kepada objek penelitian yaitu kelas 03PIEE005. Dari hasil observasi dan wawancara tidak terstruktur kepada mahasiswa pendidikan ekonomi kelas 03PIEE005 diperoleh informasi bahwa mereka sangat kurang dalam kemampuan menghitung. Menurut mereka, pada saat semester-semester sebelumnya mata kuliah yang berhubungan dengan kegiatan hitung menghitung dosen yang bersangkutan kurang memberikan latihan-latihan secara terstruktur. 
Dengan latihan-latihan seharusnya mereka lebih terlatih mengerjakan soal yang berhubungan dengan materi yang ada. Tentu hal ini menjadi point tersendiri bagi mereka guna mempersiapkan kegiatan Praktik Pengalaman Lapangan (PPL) yang menuntut mahasiswa memahami materi yang ada untuk bisa disampaikan dengan gambling kepada murid mereka kelak.

\section{Jalannya Pembelajaran Siklus I}

Kegiatan yang dilakukan pada siklus I melalui empat tahap, yaitu: perencanaan, pelaksanaan tindakan, pengamatan/observasi, dan refleksi.

\section{a. Perencanaan tindakan siklus I}

Sebelum pelaksanaan pada siklus I, maka dilakukan beberapa persiapan sebagai berikut.

1) Mengkondisikan kelas agar dapat digunakan untuk penelitian dengan memperkenalkan metode drill.

2) Mempersiapkan perangkat serta bahan yang akan dipakai selama penelitian.

\section{b. Pelaksanaan tindakan siklus I}

\section{Pertemuan I dan II}

Tahap pertama, peneliti melakukan penyajian materi. Penyajian materi disajikan secara singkat dan mencakup garis besarnya saja, kurang lebih 30 menit. Berikutnya peneliti melakukan latihan terkontrol. Setelah materi disajikan, maka langkah selanjutnya mahasiswa dapat mengerjakan soal latihan dengan arahan dan bimbingan dari dosen, yaitu selaku peneliti. Selanjutnya dosen mereview jawaban yang benar atas soal tersebut. Langkah berikutnya, peneliti melakukan latihan mandiri. Dalam tahap ini mahasiswa mengerjakan soal secara mandiri dan menyerahkan hasil pekerjaannya kepada dosen untuk dinilai. Tahap terakhir, yaitu memberikan tes secara individu. Pada tahap ini mahasiswa dapat kembali ketempat duduk masing-masing dan bersiap-siap melakukan tes individu. Soal yang diberikan pada tes ini sesuai dengan materi yang diajarkan pada saat itu. Untuk menghindari kecurangan, soal dibuat berbeda tiap individu. Dengan trik salah bagian fungsi yang ada dikalikan dengan nomer absen masing-masing. Berdasarkan hasil pengamatan peneliti ini sangat berhasil membuat mahasiswa mengerjakan soal secara mandiri tanpa mencontoh teman yang lain. 


\section{c. Observasi siklus I}

Metode pembelajaran Drill pada siklus I ini dapat dikatakan berjalan cukup baik. Walaupun pada awalnya mahasiswa masih ada yang masih kurang mengikuti pembelajaran dikarenakan mereka masih kurang paham materi yang disampaikan. Mahasiswa yang kurang paham langsung diberi pengarahan khusus oleh peneliti untuk mengatasi permasalahan belajarnya. Mahasiswa juga sudah mulai saling bertanya dengan teman terdekat mengenai kesulitan belajarnya. Hal ini menjadikan kelas lebih hidup dan aktif selama pembelajaran berlangsung. Untuk mengetahui peningkatan hasil belajar mahasiswa setelah mengikuti pembelajaran menggunakan metode Drill, maka dilaksanakan test. Soal tes berupa tes uraian yang berhubungan dengan materi yang disampaikan saat itu.

Hasil tes menunjukan bahwa mahasiswa yang tuntas test sebanyak 15 orang atau secara klasikal sebanyak $68,18 \%$. Sedangkan mahasiswa yang belum tuntas tes sebanyak 7 orang atau secara klasikal sebanyak 31,82\%.

\section{d. Refleksi siklus I}

Selama penerapan metode pembelajaran Drill, mahasiswa lebih semangat dalam belajar, mendengarkan penjelasan guru, dan aktif mengerjakan latihan soal yang diberikan. Secara keseluruhan pembelajaran pada siklus satu ini berjalan dengan cukup baik. Mahasiswa tampak bersemangat, antusias, dan termotivasi dalam belajarnya. Khususnya pada tahap pemberian latihan soal dan tes individu. Mahasiswa berlomba - lomba memperoleh nilai terbaik.

Meskipun demikian, penerapan metode pembelajaran ini masih masih terdapat kekurangan. Adapun kekurangan yang dijumpai pada siklus I, antara lain sebagai berikut:

1) Beberapa mahasiswa masih ada yang belum paham materi.

2) Siswa masih bingung dalam mengikuti model pembelajaran Drill.

3) Ada mahasiswa yang malu bertanya baik kepada teman ataupun kepada dosen mengenai kesulitan belajarnya. Hal ini berdampak pada hasil belajarnya juga kurang memuaskan.

4) Pada proses pembelajaran guru masih kurang dalam hal pengelolaan kelas dan pengelolaan waktu juga 
tidak sesuai dengan rencana pembelajaran.

5) Sebagian siswa terlihat masih kurang teliti dan terburu-buru dalam mengerjakan soal yang diberikan, sehingga ada beberapa soal yang jawabannya masih kurang benar.

\section{Treatment (Perlakuan)}

Ada beberapa hal yang dilakukan untuk mengatasi kekurangan pada siklus I di atas, antara lain:

1) Peneliti memberikan bimbingan khusus kepada mahasiswa yang masih belum paham materi yang disampaikan.

2) Peneliti memberikan penjelasan terkait dengan metode pembelajaran Drill kepada mahasiswa, terkai peran dan fungsinya selama pembelajaran berlangsung. Disamping itu peneliti juga menjelaskan apa yang boleh dan tidak boleh dilakukan selama pembelajaran tersebut.

3) Selalu menanyakan kesulitan mahasiswa dengan menghampiri tempat duduk mereka masingmasing. Hal ini diharapkan juga dapat mempererat hubungan antara dosen dan mahasiswa, sehingga lebih akrab dengan mereka dan lebih mudah pula mengetahui kesulitan belajarnya.

6) Dosen mengelola kelas lebih baik lagi terkait dengan waktu. Hal ini dilakukan dengan cara mempersiapkan lagi apa yang diperlukan selama pembelajaran berlangsung.

7) Selalu mengingatkan mahasiswa untuk selalu teliti dengan pekerjaannya. Karena sifat jawaban soal saling berhubungan antara satu dengan yang lain. Apabila dari awal salah, maka pekerjaan akan salah sampai akhir.

Semua bentuk treatment diatas tentunya dilaksanakan pada siklus II, baik pada tahap perencanaan sampai observasi.

\section{Jalannya Pembelajaran Siklus II}

a. Perencanaan tindakan siklus II

Sebelum pelaksanaan pada siklus II, maka dilakukan beberapa persiapan sebagai berikut.

1) Mengkondisikan kelas agar dapat digunakan untuk penelitian.

2) Mempersiapkan semua perangkat dan bahan penelitian. 


\section{b. Pelaksanaan tindakan siklus II}

\section{Pertemuan I dan II}

Tahap pertama, peneliti melakukan penyajian materi. Penyajian materi disajikan secara singkat dan mencakup garis besarnya saja, kurang lebih 30 menit. Berikutnya peneliti melakukan latihan terkontrol. Setelah materi disajikan, maka langkah selanjutnya mahasiswa dapat mengerjakan soal latihan dengan arahan dan bimbingan dari dosen, yaitu selaku peneliti. Selanjutnya dosen mereview jawaban yang benar atas soal tersebut. Langkah berikutnya, peneliti melakukan latihan mandiri. Tahap terakhir, yaitu memberikan tes secara individu. Pada tahap ini mahasiswa dapat kembali ketempat duduk masing-masing dan bersiap-siap melakukan tes individu. Untuk menghindari kecurangan, soal dibuat berbeda tiap individu. Dengan trik semua fungsi yang ada dikalikan dengan nomer absen masing-masing. Berdasarkan pengamatan peneliti ini sangat berhasil membuat mahasiswa lebih mandiri dan semangat selama mengerjakan soal yang diberikan tanpa berniat mencontoh teman yang lain.

\section{c. Observasi siklus II}

Metode pembelajaran Drill pada siklus II ini dapat dikatakan berjalan baik. Mahasiswa sudah mulai berani bertanya kepada dosen dan kepada teman terdekatnya secara langsung apabila ada materi yang belum dipahami. Kelas terasa lebih hidup dan pembelajaran lebih menyenangkan.

Pada sikulus II peneliti juga melakukan tes untuk mengetahui peningkatan hasil belajar siswa setelah mengikuti pembelajaran menggunakan metode Drill. Soal tes berupa tes uraian yang berhubungan dengan materi yang disampaikan saat itu.

Dari hasil tes diketahui bahwa mahasiswa yang tuntas test sebanyak 20 orang atau secara klasikal sebanyak 90,91\%. Sedangkan mahasiswa yang belum tuntas tes sebanyak 2 orang atau secara klasikal sebanyak 9,09\%. Hal ini ada peningkatan ketuntasan belajar dari 15 orang menjadi 20 orang, atau dari $68,18 \%$ menjadi 90,91\%. Dengan demikian ada peningkatan hasil belajar dari siklus I ke siklus II sebesar 22,73\%.

\section{d. Refleksi siklus I}

Pada siklus II juga dilakukan refleksi. Dimana selama penerapan metode pembelajaran Drill, mahasiswa 
lebih semangat dalam belajar, mendengarkan penjelasan guru, dan aktif mengerjakan latihan soal yang diberikan. Secara keseluruhan pembelajaran pada siklus II sangat baik terbukti dengan mahasiswa lebih semangat dan hasil belajar yang diperoleh juga memuaskan. Mereka berharap metode pembelajaran ini dapat juga diterapkan oleh dosen-dosen lain terutama yang mengampu mata kuliah hitungan.

\section{TEMUAN PENELITIAN}

Selama penelitian, peneliti menemukan bahwa penerapa metode pembelajaran Drill sangat membantu mahasiswa dalam memahami materi yang disampaikan. Dengan latihanlatihan mereka bisa lebih melatih kemampuan mereka dalam menghitung. Mahasiswa juga bisa secara langsung menanyakan apa yang tidak dimengerti kepada dosen yang bersangkutan atau teman terdekat. Pada awalnya memang mereka masih agak bingung dengan metode yang dipakai. Mereka masih kurang terbiasa mengerjakan latihanlatihan soal yang diberikan. Akan tetapi lambat laun mereka mulai terbiasa dan belajar seperti sangat menyenangkan sekali. Menurut mereka, ini merupakan pengalaman baru dan sangat membantu mereka untuk mengasah kemampuan khususnya mereka yang kurang suka berhitung.

Hasil belajar dalam bentuk tes disetiap akhir siklus juga menunjukkan hasil yang bisa dikatakan baik. Terdapat peningkatan hasil belajar dari siklus I ke siklus II sebesar 22,73\%.

\section{PEMBAHASAN}

\section{Penerapan Metode Drill pada} Mata Kuliah Matematika

\section{Ekonomi}

Ada beberapa tahapan yang dilaksanakan dalam kegiatan pembelajaran dengan penerapan metode Drill.

Tahapan pertama, penyajian materi. Pada tahap ini penyajian materi disajikan oleh peneliti secara singkat dan mencakup garis besarnya saja. Peneliti menyiapkan materi dalam bentuk power point dan membagikan kepada mahasiswa sebelum pelaksanaan penelitian supaya dipelajari.

Tahap kedua, latihan terkontrol. Setelah materi disajikan, mahasiswa dapat mengerjakan soal latihan dengan arahan dan bimbingan dari dosen. Selanjutnya dosen mereview jawaban 
mahasiswa satu persatu dari jawaban yang benar atas soal tersebut.

Tahap ketiga, latihan mandiri. Pada tahap ini mahasiswa mengerjakan soal secara mandiri dan menyerahkan hasil pekerjaannya kepada dosen untuk dinilai.

Tahap keempat, tes. Pada tahap terakhir ini mahasiswa dapat kembali ketempat duduk masing-masing dan bersiap-siap melakukan tes individu. Soal yang diberikan pada tes ini sesuai dengan materi yang diajarkan pada saat itu.

\section{Hasil Belajar Matematika Ekonomi Mahasiswa dengan Penerapan Metode Drill}

Hasil belajar mahasiswa setelah diterapkannya metode pembelajaran Drill telah menunjukkan suatu perbedaan dari hasil perolehan tes. Hasil belajar mahasiswa dari siklus I ke siklus II juga mengalami peningkatan. Walaupun data tes hasil tindakan menunjukkan peningkatan, namun peneliti belum dapat menyatakan bahwa peningkatan tersebut sepenuhnya hasil dari penerapan metode Drill (latihan). Hal ini disebabkan karena masih banyak faktor lain yang menyebabkan siswa dapat menyelesaikan tugas atau dapat menjawab soal tes dengan baik, faktorfaktor lain tersebut tidak semua dipertimbangkan dalam penelitian ini.

\section{KESIMPULAN}

1. Ada beberapa tahapan yang dilaksanakan dalam kegiatan pembelajaran dengan penerapan metode Drill, antara lain: (1) penyajian materi; (2) latihan terkontrol; (3) latihan mandiri; dan (4) tes.

2. Hasil belajar dalam bentuk tes disetiap akhir siklus I dan II mengalami peningkatan. Berdasarkan hasil penelitian menunjukkan bahwa dari 22 orang mahasiswa aktif selama penelitian, pada siklus I menunjukkan sebanyak 15 mahasiswa lulus atau secara klasikal 68,18\%. Sedangkan mahasiswa yang tidak lulus sebanyak 7 orang atau secara klasikal sebesar 31,82\%. Sedangkan pada siklus II mahasiswa yang tuntas tes sebanyak 20 orang atau secara klasikal sebesar 90,91\%. Sedangkan mahasiswa yang belum tuntas tes sebanyak 2 orang atau secara klasikal sebanyak 9,09\%. Hal ini ada peningkatan ketuntasan hasil belajar dari 15 orang menjadi 20 
orang, atau dari $68,18 \%$ menjadi 90,91\%. Dengan demikian dapat disimpulkan bahwa ada peningkatan hasil belajar dari siklus I ke siklus II sebesar $22,73 \%$.

\section{DAFTAR PUSTAKA}

Anita lie. 2008. Cooperative Learning, Jakarta: Grasindo.
Suherman. 2001. Pengertian Belajar dan Belajar Matematika. Dalam www.masbi ed.com/2010/02/19.

Sagala, Syaiful. 2011. Konsep dan Makna Pembelajaran. Bandung: Alfabeta. 